Eğilmez. N. i. (2018). Türkçe öğretmeni adaylarının “özel durumlarda” kullandıkları kalıp sözler. Ana Dili Eğitimi Dergisi, 6(3), 840-858.

$\begin{gathered}\text { Ana Dili Eğitimi Dergisi } \\ \text { Journal of Mother Tongue Education } \\ \text { www.anadiliegitimi.com }\end{gathered}$
Gelis/Received: 29.06 .2018 Kabul/Accepted:19.07.2018

\title{
Türkçe Öğretmeni Adaylarının “Özel Durumlarda” Kullandıkları Kalıp Sözler
}

\author{
Nigar IPEK EĞILMEZ*
}

\section{Öz}

Atasözleri, deyimler, ikilemeler gibi kalıplaşmış dil birimlerinden biri olan "kalıp sözler" özellikle sözlü iletişimin en güçlü unsurlarındandır. Türkçe dersi hem kullandığı malzeme olan metinler hem de iletişim becerileri aracılığıyla, çocuğu, içinde yaşadığı toplumla uyumlu bir birey haline getirme konusunda önemli bir yere sahiptir. Bu önemden yola çıkarak ileride Türkçe öğretmeni olacak olan Türkçe öğretmeni adaylarının "özel durumlarda” kullandıkları kalıp sözleri tespit etmek bu çalışmanın amacını oluşturmaktadır. Bu amaç doğrultusunda 2015-2016 eğitim öğretim yılında Muğla Sıtkı Koçman Üniversitesi Eğitim Fakültesi Türkçe Eğitimi Bölümü’nde öğrenim görmekte olan 173 öğretmen adayına "Kalıp Söz Kullanma Testi” uygulanmıştır. Türkçe öğretmeni adaylarının "Kalıp Söz Kullanma Testinde" yer alan bağlamlara yazdıkları cevaplar incelendiğinde, özel durumlarda kullandıkları kalıp sözlere ilişkin "doğum”, “ölüm”, "nişan/evlilik”, "başarı”, "mal/mülk edinme", "bayram ziyareti" ve "hasta ziyareti" olmak üzere 7 bağlam ortaya çıkmıştır. Elde edilen veriler Simple Concordance Program 4.07, SPSS 22 ve Microsoft Excel Programları kullanılarak çözümlenmiştir. Araştırma sonucunda, cinsiyete göre, kızların erkeklerden daha fazla kalıp söz kullandıkları; bağlamlarına göre kalıp söz kullanımı açısından ise Türkçe öğretmeni adaylarının en çok "ölüm" ve "doğum" konularında farklı kalıp söz kullandıkları tespit edilmiştir. İleride Türkçe öğretmeni olacak öğretmen adaylarının, öğrencilerine örnek olabilmesi ve dil becerileri aracılığı ile kültür aktarımı yapabilmesi açısından kalıp söz kullanmalarının oldukça önemli olduğu düşünülmektedir.

Anahtar Kelimeler: Kelime hazinesi, kalıp sözler, ilişki sözleri, öğretmen adayı

\section{Formulaic Expressions Used by Prospective Turkish Teachers on "Special Occasions"}

\begin{abstract}
"Formulaic expressions" which are one type of fixed language units like proverbs, idioms, and reduplications are among the most powerful elements of verbal communication. In terms of both the texts used and through communication skills, the Turkish course has an important role in making children become individuals who are well adjusted to the society in which they live. Taking this view as its starting point, the purpose of this study was to determine the words prospective Turkish teachers used on "special occasions". For this purpose, the "Formulaic Expression Use Test" developed by the researcher was administered to 173 prospective teachers who were studying in the department of Turkish Education of Muğla Sıtkı Koçman University Faculty of Education in the 2015-2016 academic year. When examining the responses given by the prospective Turkish teachers in the contexts given in the "Formulaic Expression Use Test", seven contexts in which they used formulaic expressions emerged which are "birth", "death", "engagement/marriage", "success", "acquisition of property", "eid visit" and "patient visit ". The obtained data were analyzed, using Simple Concordance Program 4.07, SPSS 22, and Microsoft Excel software. The results showed that, in terms of gender, females used more formulaic expressions than males, and that, in terms of context, prospective Turkish teachers used formulaic expressions the most for
\end{abstract}

*Dr. Öğretim Üyesi, Muğla Sıtkı Koçman Üniversitesi Eğitim Fakültesi, Sosyal Bilgiler ve Türkçe Eğitimi Bölümü, Türkçe Öğretmenliği Programı, Muğla, nigaripek@mu.edu.tr 


\begin{abstract}
"death" and "birth". It is considered highly important for prospective Turkish teachers to be able to use formulaic expressions in forming an example for their students and transferring culture through language skills.
\end{abstract}

Keywords: Vocabulary, Formulaic expressions, Phrases for social relations, Prospective teacher

\title{
Giriş
}

Yapılan tüm dil tanımlarında, dilin duygu ve düşünceleri aktarma; anlama ve anlatma aracı olmasından yola çıkarak insanlar arasında iletişimi sağlayan bir unsur olduğu vurgulanmıştır. Dil insanlar arasındaki iletişimin bir aracı olduğu kadar, geçmişten günümüze kültür aktarımı yapan bir köprüdür aynı zamanda. Dil konuşulduğu toplumun en ayırt edici unsurlarından biridir; o toplumun parmak izidir. Aksan (2003, s. 64) insanı insan yapan dilin, toplumun temel taşı olduğunu ve ulusu ulus yapan ögelerin başında geldiğini ve dilin, kültürün belkemiği olduğunu ifade etmektedir. Güvenç'e göre (1196, s. 45), "...dil ile kültür birbirine eşdeğer, iki bağımsız birim değil, tek bir varlığın, birbirinden ayrılmaz, biri ötekisiz olmaz iki parçası gibidir. Kültürde ne varsa dilde vardır. Dildeki her şey kültürden gelir. Kültür dilde yaşar, gelişir, birikir. Dil kültürün hazinesi, bilinci, ruhudur." Humboldt ise "ulusun dili ruhudur; ruhu da dili" diyerek dilin kültür üzerindeki önemini ortaya koymaktadır (Aksan, 2003, s. 65).

Dildeki bu kültür aktarımı görevini üstlenen en önemli unsurlardan biri ise dilin söz varlığıdır. Bir dilin söz varlığı, konuşulduğu toplumun geçmişini, inançlarını, yaşam biçimini, ruhunu yansıtır. Geçmişle gelecek arasında bağ kurar, sürekliliği sağlar.

Söz varlığı, sadece bir dilde bir takım seslerin bir araya gelmesiyle kurulmuş simgeler, kodlar ya da dilbilimdeki terimiyle göstergeler- olarak değil, aynı zamanda o dili konuşan toplumun kavramlar dünyası, maddi ve manevi kültürünün yansıtıcısı, dünya görüşünün bir kesiti olarak düşünülmelidir (Aksan, 2015, s. 15).

Söz varlığı tek tek sözcüklerin toplamından ibaret değildir; sözcüklerin yanı sıra deyimlerin, atasözlerinin, ikilemelerin, kalıp sözlerin, terimlerin, çeviri sözcüklerin oluşturduğu büyük bir anlam bütünüdür. Söz varlığı bir dildeki sözcüklerin toplamından çok daha fazlasıdır.

Söz varlığı unsurları içerisinde kültür aktarımı görevini üstlenen en önemli yapılar ise atasözleri, deyimler, ikilemeler, birleşikler ve kalıp sözlerden oluşan "kalıplaşmış dil birimleri" dir (Gökdayı, 2015, s. 33). Gökdayı'ya göre (2015, s. 53-55), kalıplaşmış dil birimlerinin ortak yönleri kalıplaşmış olmaları, anlık oluşum içermemeleri, tek bir birim olarak işlem görmeleri, sabit öge dilimine sahip olmaları, birden fazla sözcükle tek bir anlam ifade etmeleri, üst saymaca oluşları ve kültür taşıyıcısı olmalarıdır.

Kalıp sözler hem sözlü hem yazılı iletişimin en güçlü unsurlarındandır. Söylemek istediklerimizi bir seferde ve en kısa yoldan aktarmamızı sağlayan oldukça etkili dilsel araçlardır. Kalıp sözlerin içinde söylenmek istenenin yanı sıra duygular, atalarımızdan miras kalan kültür hazinesinin parçaları yer almaktadır. Her toplum kendi kalıp sözleri ile birlikte aslında toplumsal beklentilerini, duygulanımlarını 
ve samimiyetini dışa vurur. Bu samimiyet iletişime olumlu bir yansıma yaparak kişileri birbirine bağlar, toplumsal birlikteliğin oluşmasına katkı sağlar.

Kalıp sözler, toplumun uzun yıllar öncesine dayanan yaşanmışlıklarından bir başka deyişle; ürettiklerinden, deneyimlerinden, acılarından, sevinçlerinden meydana gelmiştir. Bir "kalıplaşmış dil biriminin" içerisinde o toplumun yıllar önce benzer bir durumda hissettikleri vardır. O duygu o "söz"ün içine sinmiştir. Örneğin çocuk sahibi olan birine "Allah analı babalı büyütsün", "uzun ömürlü olsun", "Allah dört gözden ayırmasın" derken veya sevdiği bir yakını yitiren birine "mekânı cennet olsun", "nur içinde yatsın" derken ortaya çıkan duyguyu başka hiçbir dil birimiyle ifade etmek mümkün değildir. Tıpkı diğer kalıplaşmış dil birimlerini kullanırken olduğu gibi, kalıp sözleri kullanırken, bir taraftan dilden tasarruf sağlandığı gibi öte yandan söylenmek istenen söz etkili bir şekilde pekiştirilmiş olur. Wray (2002, s. 18), kalıplaşmış sözlerin çokça kullanılmasının nedenlerinden biri olarak, bu sözlerin zihinde hazır halde bulunuşunu ve çok fazla çaba gerektirmeden hemen söylenip anlaşılabilmesini göstermektedir (Akt. Gökdayı, 2008, s. 90).

Kalıp sözler zaman zaman farklı isimlerle de ifade edilmektedir. Toplumsal ilişkileri düzenlemesinden yola çıkarak Aksan $(2014,2015)$ kalıp sözleri "ilişki sözleri” olarak da kullanmıştır.

“... kalıp sözler ya da ilişki sözleri adı verilen ögeler-tıpkı deyimler ve atasözleri gibi- bir dili konuşan toplumun kültürüne ışık tutmakta, onun inançlarını, insan ilişkilerindeki ayrıntıları, gelenek ve görenekleri yansıtmaktadır." (Aksan, 2015, s. 201).

Kalıp sözleri "kültür birim" olarak adlandıran Kula (1996, s. 46) kalıp sözler için "Türk kültürünü ne denli yansıttığının bir göstergesidir." ifadesini kullanmaktadır.

Türkçede söz varlığı üzerine yapılan çalışmalar incelendiğinde bugüne kadar atasözleri ve deyimler üzerine birçok çalışma yapıldığı görülmektedir. Kalıp sözler üzerine yapılan çalışmaların atasözleri ve deyimlere kıyasla daha az olduğu fakat son yıllarda yapılan çalışmaların sayısında artış olduğu görülmektedir (Zülfikar, 2007; Gökdayı, 2008; Sis ve Gökçe, 2009; Yazıcı Okuyan, 2012; Canbulat ve Dilekçi, 2013; Ünsal, 2013; Yılmaz ve Ertürk Şenden, 2014; Gökdayı, 2015; Kara ve Memiş; 2015; Topçuoğlu Ünal ve Bursalı, 2015; Gökdayı, 2016; İlhan, 2017; İpek Eğilmez, 2017; Kara ve Yıldııım, 2017; Uzcu Yıldız, 2017). Bunun yanı sıra son yıllarda konu ile ilgili çalışılan tezlerin sayısında da artış olmuştur (Erol, 2007; Bulut, 2012; Koç, 2015; Çaydaş, 2016; Ertürk Şenden, 2017). Kalıp sözler üzerine özellikle son yıllarda yapılan çalışmaların büyük kısmının ise yabancılara Türkçe öğretimi üzerine oluşu dikkat çekicidir (Yılmaz ve Ertürk Şenden, 2014; Kara ve Memiş; 2015; Yılmaz ve Ertürk Şenden, 2015; Çaydaş, 2016; Gökdayı, 2016; Ertürk Şenden, 2017; Koç, 2015; Uzcu Yıldız, 2017).

Kalıp sözler üzerine yapılan tüm bu çalışmalar incelendiğinde, kalıp sözlerin farklı şekillerde sınıflandırıldığı göze çarpmaktadır. Konu ile ilgili yapılan en kapsamlı çalışmalardan biri olan "Türkçede 
Kalıp Sözler" adlı çalışmada, Gökdayı (2008), kalıp sözleri "yapı, işlev, anlam ve bağlamlarına" göre sınıflandırmıştır. Kalıp sözler, anlamlarına göre; "selamlaşma; ayrılık; hayır dua ve iyi dilek; küfür, beddua-ilenç; batıl inanç; dini inanç; bir istek; konuşanı veya dinleyeni yüceltme; bir isteği kabul veya reddetme; dinleyeni eleştirme, uyarma, tehdit etme; genel bir davranış veya düşünce; özür dileme; sembolik olarak ödüllendirme; teşekkür, minnet bildiren kalıp sözler ile töre, gelenek ve kültürel değerleri yansıtanlar, soru sorup cevap isteyenler, duygusal tepkileri dile getirenler (korku, sevinç, şaşkınlık, acıma, çağıı, buyruk, yasaklama, vb.)" olmak üzere on yedi grupta ele alınırken; bağlamlarına göre "üzüntü veya strese neden olan olaylarda söylenenler", "mutluluk veren olaylarda söylenenler" ve "yakın ilişki kurmak istenilen durumlarda söylenenler" olmak üzere üç başlıkta ele almıştır (Ippek Eğilmez, 2017, s. 788).

Bunun dışında kalıp sözler, "doğrudan kalıp cümleler, kalıp cümle yapısındaki hayır dualar, kalıp cümle yapısındaki beddualar, çeviri yoluyla dile giren bazı kullanımlar (Zülfikar, 2007)"; "hayır dualar, beddualar ve toplumsal-kültürel ilişkileri yansıtan kalıp sözler (Yazıcı Okuyan, 2012; Canbulat ve Dilekçi, 2013, Topçuoğlu Ünal ve Bursalı, 2015)"; "kibarlık ifade eden, küfür ifade eden, iyi dilekte bulunmayla ilgili, özel durum ile ilgili (kız isteme, nişan, düğün, doğum...), başsağlığı ile ilgili, batıl inançla ilgili, dini inanç ve kaderle ilgili, hayır dua ile ilgili, beddua ile ilgili, söz verme ile ilgili kalıp sözler ile yüceltme için kullanılanlar ve onaylama için kullanılanlar (Ünsal, 2013)"; "hayır dualar, beddualar, yeminler, günlük hayatta kullanılanlar (Erol, 2007)"; "gün içinde kullanılan kalıp ifadeler (selamlaşma, vedalaşma, tanışma vb.), kutlama ifadeleri, dilek ve temenni ifadeleri, dini inanç ve kültürle ilgili kalıp ifadeler (Kara ve Memiş, 2015)"; "günlük yaşamda kullanılan ve özel durumlarda kullanılan kalıp sözler (İpek Eğilmez, 2017)" olmak üzere birçok farklı şekilde ele alınmıştır.

Kalıp sözler genel olarak toplumsal kültürel ilişkileri düzenleyen sözler olması dolayısıyla kullanıldığı bağlama göre "günlük yaşamda kullanılan" ve özel durumlarda kullanılan" kalıp sözler olarak da incelenebilir. Günlük yaşamı düzenleyen kalıp sözlerin içerisinde selamlaşma, hâl hatır sorma, tanışma, özür dileme gibi günlük yaşamın hemen her anında karşılaşılması olağan olan sıradan durumlar ele alınabilir. Başsağlığı dileme, doğum, evlilik gibi özel durumlarda kullanılan kalıp sözler ise asıında günlük yaşamımızın bir parçası olmasına rağmen, özel durumlar olması nedeniyle günlük yaşamı düzenleyen kalıp sözlerden ayrı tutularak incelenebilir.

Dilin bir parçası olan kalıp sözler aynı zamanda dil öğretiminin de bir parçası olmalıdır. Etkili bir dil öğretiminde, Türkçe öğretim programının ve ders kitaplarının yanı sıra programın uygulayıcısı olan Türkçe öğretmenlerinin önemi çok büyüktür. Doğrudan etkileşime dayalı olan Türkçe derslerinde öğrenciler, dinleyerek, konuşarak, okuyarak ve yazarak anadillerinin zenginliklerini keşfeder, bu zenginlikleri kullanma becerisine sahip olurlar. Türkçe dersi bir beceri dersidir. Doğrudan, dili kullanarak, yaparak ve yaşayarak çocuk dil becerisini geliştirir. Bu nedenle öğrencinin, dil açısından 
zengin metinlerle karşılaşması kadar dili iyi kullanan öğretmenlerle de etkileşim halinde olması oldukça önem taşımaktadır. Bu noktadan hareketle Türkçe öğretmenliği programında öğrenim gören öğretmen adaylarının kalıp sözlere ne derece hâkim olduklarını tespit etmek bu çalışmanın temel amacını oluşturmaktadır.

\section{Yöntem}

\section{Araştırmanın Modeli}

Türkçe öğretmeni adaylarının “özel durumlarda” kullandıkları kalıp sözleri kullanma düzeylerini tespit etmek amacıyla yapılan bu çalışmada, betimleme amacı güden tarama modeli kullanılmıştır. Var olan durumu olduğu gibi ortaya koyma amacı güdülen tarama modelinde "araştırmaya konu olan olay, birey ya da nesne kendi koşulları içinde ve olduğu gibi tanımlanmaya çalışılır." (Karasar, 1999: 77).

Çalışma grubu

2015-2016 eğitim-öğretim yılında Muğla Sıtkı Koçman Üniversitesi Eğitim Fakültesi Türkçe Eğitimi Bölümünde öğrenim gören 173 öğretmen adayı bu araştırmanın çalışma grubunu oluşturmuştur. Çalışmaya katılmaya gönüllü olan öğretmen adaylarının 41'i birinci sınıf, 45’i ikinci sınıf, 45’i üçüncü sınıf ve 42'si dördüncü sınıf öğrencisidir. Ayrıca bu öğrencilerin 103'ü kız, 70'i erkektir. Çalışma grubu belirlenirken amaçsal örnekleme yöntemi kullanılmıştır. Amaçsal örnekleme yöntemi "belli ölçütleri karşılayan veya belli özelliklere sahip olan bir veya daha fazla özel durumlarda çalışılmak istenildiğinde” tercih edilir (Büyüköztürk vd., 2013: 90). Aşağıdaki tabloda çalışma grubunda yer alan öğretmen adaylarının cinsiyetlerine ve sınıf düzeylerine göre dağııımı yer almaktadır.

Tablo 1: Çalışma Grubu Tablosu

\begin{tabular}{|c|c|c|c|c|c|c|c|c|c|c|c|}
\hline \multirow{3}{*}{\multicolumn{2}{|c|}{ Değişkenler }} & \multicolumn{8}{|c|}{ Sinif } & & \\
\hline & & \multicolumn{2}{|r|}{1} & \multicolumn{2}{|c|}{2} & \multicolumn{2}{|r|}{3} & \multicolumn{2}{|r|}{4} & \multicolumn{2}{|c|}{ Toplam } \\
\hline & & $\mathrm{n}$ & $\%$ & $\mathrm{n}$ & $\%$ & $\mathrm{n}$ & $\%$ & $\mathrm{n}$ & $\%$ & $\mathrm{n}$ & $\%$ \\
\hline \multirow{2}{*}{ Cinsiyet } & $\mathrm{K} \mathrm{Iz}$ & 23 & 56 & 31 & 69 & 26 & 58 & 23 & 55 & 103 & 60 \\
\hline & Erkek & 18 & 44 & 14 & 31 & 19 & 42 & 19 & 45 & 70 & 40 \\
\hline Toplam & & 41 & 24 & 45 & 26 & 45 & 26 & 42 & 24 & 173 & 100 \\
\hline
\end{tabular}

Çalışmaya katılan öğretmen adaylarının \%24'ü birinci sınıf, \%26'sı ikinci sınıf, \%26'sı üçüncü sınıf ve \%24'ü dördüncü sınıftır. Cinsiyete göre değerlendirildiğinde katılımcıların \%60'ı kız ve \%40'ı erkektir. Öğretmen adaylarının sınıf düzeylerine göre dağılımı birbirine oldukça yakınken, cinsiyete göre dağılımlarında kızların erkeklerden daha fazla olduğu görülmektedir. Bu durum çalışmanın yapıldığı eğitim fakültesinin genel dağılımından kaynaklanmaktadır.

\section{Veri Toplama Araçları}

Verilerin toplanabilmesi için araştırmacı tarafından geliştirilen "Kalıp Söz Kullanma Testi" kullanılmıştır. Öncelikle ilgili alanyazın taranarak, dilimizde, "özel durumlarda” kullanılabilecek kalıp sözler tespit edilmiş ve bu sözlerin hangi bağlamlarda kullanılabileceğine ilişkin örnek durum cümleleri 
belirlenmiştir. Testin bu taslak hali altı alan uzmanı tarafından incelenmiş ve yapılan öneriler doğrultusunda test son halini almıştır. Öğretmen adaylarından beklenen ise söz konusu örnek durumlarda hangi kalıp sözü ya da sözleri kullandıklarını yazmaları olmuştur.

Türkçe öğretmeni adaylarının "Kalıp Söz Kullanma Testinde” yer alan bağlamlara yazdıkları cevaplar incelendiğinde, özel durumlarda kullandıkları kalıp sözlere ilişkin 9 farklı bağlam ortaya çıkmıştır. Çalışmanın kapsamı doğrultusunda daha çok öne çıkan “doğum”, “ölüm (baş sağlığı)”, "nişan/evlilik", "başarı", "mal/mülk edinme", "bayram ziyareti” ve "hasta ziyareti” olmak üzere 7 bağlam değerlendirmeye alınmıştır. Bu sebeple öğretmen adaylarından elde edilen veriler söz konusu 7 başlık altında ele alınarak değerlendirilmiştir.

\section{Verilerin Çözümlenmesi}

Verilerin çözümlenmesi amacıyla öncelikle öğretmen adaylarının kullandıkları kalıp sözler bağlamlarına göre gruplara ayrılmış ve tekrar eden kalıp sözlerin sıklıkları belirlenerek ilgili bağlamın altında listelenmiştir. Tüm bu işlemler "SPSS 22", "Simple Concordance Program 4.07" ve "Microsoft Excel" programları kullanılarak gerçekleştirilmiştir. Elde edilen veriler, Türkçe öğretmeni adaylarının kullandıkları kalıp sözlerin "toplam sıklığı (frekans)" ve "madde başı" kullanım sayısı olarak çözümlenmiştir.

Toplam kalıp söz sayısı (sıklık), bir kalıp sözün öğretmen adaylarının tamamı tarafından kaç kez tekrarlandığını ifade ederken; madde başı kalıp söz sayısı, öğretmen adaylarının kaç farklı çeşitte kalıp söz kullandığını ifade etmektedir.

\section{Bulgular}

Bu bölümde, elde edilen bulgular iki ana başlık altında sunulmuştur. ilk olarak "Türkçe öğretmeni adaylarının özel durumlarda kullandıkları kalıp sözlere ilişkin sayısal bulgular" başlığı altında, cinsiyete göre öğretmen adaylarının kullandıkları kalıp sözlerin toplam sıklığı ile madde başı kullanımı ele alınmıştır. İkinci olarak "Türkçe öğretmeni adaylarının özel durumlarda kullandıkları kalıp sözler" başlığı altında her bir bağlama ilişkin kullanılan kalıp sözler sıklıklarına göre listelenmiştir.

\section{Türkçe Öğretmeni Adaylarının Özel Durumlarda Kullandıkları Kalıp Sözlere Ilişkin Sayısal Bulgular}

Öğretmen adaylarının kullandıkları kalıp sözlerin toplam sıklığı ve madde başı olarak kullanımına ilişkin genel sayısal bulgular, cinsiyete göre incelenmiştir. Çalışmaya katılan kız ve erkek öğretmen adaylarının sayıları eşit olmadığı için, tablolar yorumlanırken, ortalama ve yüzdeler dikkate alınmıştır.

Tablo 1.1. Türkçe öğretmeni adaylarının özel durumlarda kullandıkları kalıp sözlere ilişkin genel veriler

\begin{tabular}{llllll}
\hline \multirow{2}{*}{ Cinsiyet } & $\mathrm{n}$ & \multicolumn{2}{l}{ Toplam Kalıp Söz Sayısı (Sıklık) } & \multicolumn{2}{l}{ Madde Başı Kalıp Söz Sayısı } \\
\cline { 2 - 5 } & $\mathrm{f}$ & Ortalama & $\mathrm{f}$ & Ortalama \\
\hline
\end{tabular}


Türkçe Öğretmeni Adaylarının “Özel Durumlarda” Kullandıkları Kalıp Sözler

\begin{tabular}{llllll}
\hline Kız & 103 & 1161 & 11,3 & 66 & 0,6 \\
\hline Erkek & 70 & 735 & 10,5 & 47 & 0,7 \\
\hline Toplam & 173 & 1896 & 11 & 72 & 0,4 \\
\hline
\end{tabular}

Çalışmaya katılan 173 Türkçe öğretmeni adayı toplamda 72 farklı (madde başı) kalıp söz kullanırken, kalıp sözlerin toplam kullanım sıklığı 1896 olarak tespit edilmiştir. Cinsiyet bağlamında kullanılan toplam kalıp söz sayısı açısından kızların $(11,3)$ erkeklerden $(10,5)$ biraz daha fazla sayısı kalıp söz kullandıkları belirlenmiştir. Madde başı kalıp sözlerin ortalamalarına bakıldığında (Kız: 0,6; Erkek: $0,7)$ sonuçların kızlar ve erkekler açısından neredeyse aynı olduğu görülmüştür.

Tablo 1.2. Özel durumda kullanılan kalıp sözlerin "toplam sıklık" düzeyi

\begin{tabular}{lcccccc}
\hline \multirow{2}{*}{ Özel Durumlarda Kullanılan Kalıp Sözler } & \multicolumn{2}{c}{ Kız } & \multicolumn{2}{c}{ Erkek } & \multicolumn{2}{c}{ Toplam } \\
\cline { 2 - 8 } & $\mathrm{f}$ & $\%$ & $\mathrm{f}$ & $\%$ & $\mathrm{f}$ & $\%$ \\
\hline Ölüm (baş sağlığı) & 276 & 23,8 & 164 & 22,3 & 440 & 23,2 \\
\hline Nişan/Evlilik & 253 & 21,8 & 164 & 22,3 & 417 & 22,0 \\
\hline Hasta ziyareti & 139 & 12 & 82 & 11,2 & 221 & 11,7 \\
\hline Bayram ziyareti & 128 & 11 & 92 & 12,5 & 220 & 11,6 \\
\hline Başarı & 131 & 11,3 & 81 & 11 & 212 & 11,2 \\
\hline Mal/Mülk edinme & 125 & 10,8 & 83 & 11,3 & 208 & 11 \\
\hline Doğum & 109 & 9,4 & 69 & 9,4 & 178 & 9,4 \\
\hline Toplam & 1161 & 100 & 735 & 100 & 1896 & 100 \\
\hline
\end{tabular}

Yukarıdaki tabloda öğretmen adaylarının özel durumlarda kullandıkları kalıp sözlerin toplam sıklığı, bağlamlarına göre ele alınmıştır. Burada kalıp sözlerin, hangi bağlamlarda daha çok kullanıldığı bir başka deyişle daha çok tekrar ettiği görülmektedir. Öğretmen adayları en çok “ölüm $(\% 23,2)$ ” ve "nişan/evlilik (\%22)" bağlamlarında kalıp söz söylemişlerdir. Bunu sırasıyla "hasta ziyareti $(\% 11,7)$, bayram ziyareti $(\% 11,6)$, başarı $(\% 11,2)$ ve mal/mülk edinme (\%11) durumları takip etmiştir. Tüm bunların içerisinde, öğretmen adayları, en az “doğum $(\% 9,4)$ ” ile ilgili kalıp söz söylemişlerdir.

Tablo 1.3. Özel durumda kullanılan kalıp sözlerin çeşitliliği (madde başı olarak)

\begin{tabular}{lcccccc}
\hline \multirow{2}{*}{ Özel Durumlarda Kullanılan Kalıp Sözler } & \multicolumn{2}{c}{ Kız } & \multicolumn{2}{c}{ Erkek } & \multicolumn{2}{c}{ Toplam } \\
\cline { 2 - 7 } & $f$ & $\%$ & $f$ & $\%$ & $f$ & $\%$ \\
\hline Ölüm (baş sağlığı) & 20 & 30,3 & 14 & 29,8 & 22 & $\mathbf{3 0 , 6}$ \\
\hline Doğum & 14 & 21,2 & 10 & 21,3 & 16 & $\mathbf{2 2 , 2}$ \\
\hline Nişan/Evlilik & 11 & 16,7 & 11 & 23,4 & 13 & 18,1 \\
\hline Başarı & 8 & 12,1 & 7 & 14,9 & 10 & 13,9 \\
\hline Mal/Mülk edinme & 7 & 10,6 & 3 & 6,4 & 7 & 9,7 \\
\hline Bayram ziyareti & 5 & 7,6 & 5 & 10,6 & 5 & 6,9 \\
\hline Hasta ziyareti & 5 & 7,6 & 2 & 4,3 & 5 & 6,9 \\
\hline Toplam & 66 & 100 & 47 & 100 & 72 & 100 \\
\hline
\end{tabular}

Tablo 1.3'te Türkçe öğretmeni adaylarının, madde başı olarak, kaç farklı kalıp söz kullandığı görülmektedir. Tabloya göre öğretmen adayları \%30,6 ile en çok ölüm (baş sağlığı) ve \%22 ile doğum bağlamlarında farklı kalıp söz söylemişlerdir. Bir başka deyişle, öğretmen adayları, en çok ölüm ve doğum bağlamlarında kalıp söz çeşitliliğine ve zenginliğine sahiptirler. Bunu sırasıyla nişan/evlilik $(\% 18,1)$, başarı $(\% 9,7)$, bayram ziyareti ve hasta ziyareti $(\% 6,9)$ takip etmiştir. 


\section{Türkçe Öğretmeni Adaylarının Özel Durumlarda Kullandıkları Kalıp Sözler}

Bu bölümde Türkçe öğretmeni adaylarının özel durumlarda kullandıkları kalıp sözler, "doğum", “ölüm (baş sağlığı)", "nişan/evlilik", "başarı", "mal-mülk edinme”, "bayram ziyareti” ve "hasta ziyareti” olmak üzere yedi bağlam üzerinden verilmiştir.

Türkçe öğretmeni adaylarının ölüm durumunda söyledikleri kalıp sözler listelendiğinde sözlerin bir kısmının ölen için bir kısmının ise ölenin yakını için söylendiği görülmüştür. Bu nedenle kalıp sözlerin daha net bir şekilde ortaya konulabilmesi için ölüm durumunda söylenen sözler iki ayrı tabloda ele alınmıştır.

Tablo 2.1. Türkçe öğretmeni adaylarının "ölüm” için kullandıkları kalıp sözler (ölen için söylenen kalıp sözler)

\begin{tabular}{lcc}
\hline Kalıp Sözler: Ölüm (Ölen kişi için söylenen) & Toplam Sıklık (f) & Yüzde (\%) \\
\hline Allah rahmet eylesin & 93 & 38,8 \\
\hline Allah mekanını cennet etsin/mekanı cennet olsun & 82 & 34,2 \\
\hline Allah taksiratını affetsin & 30 & 12,5 \\
\hline nur içinde yatsın & 11 & 4,6 \\
\hline Allah günahlarını affetsin & 9 & 3,8 \\
\hline Allah toprağını bol etsin/toprağı bol olsun & 8 & 3,3 \\
\hline ruhu şad olsun & 3 & 1,3 \\
\hline Allah yattığı yerde dinlendirsin & 2 & 0,8 \\
\hline Hakkın rahmetine kavuştu & 1 & 0,4 \\
\hline Peygamberin şefaati üzerine olsun & 1 & 0,4 \\
\hline Toplam & 240 & 100 \\
\hline
\end{tabular}

Yukarıdaki tabloda Türkçe öğretmeni adaylarının ölen kişi için söylediği kalıp sözler listelenmiştir. Öğretmen adayları ölen kişinin ardından en çok "Allah rahmet eylesin (\%38,8)", ve "Allah mekânını cennet etsin/mekânı cennet olsun (\%34,2)” kalıp sözlerini kullanmışlardır. Bunun yanı sıra "Allah taksiratını affetsin (\%12,5)", "nur içinde yatsın (\%4,6)", "Allah günahlarını affetsin $(\% 3,8)$ ”, "Allah toprağını bol etsin/toprağı bol olsun (\%3,3)", "ruhu şad olsun (\%1,3)", "Allah yattığı yerde dinlendirsin $(\% 0,8)$ ", "Hakkın rahmetine kavuştu $(\% 0,4)$ " ve "Peygamberin şefaati üzerine olsun $(\% 0,4)$ ifadeleri kullanılmıştır. Yine tabloya göre öğretmen adaylarının ölen kişinin ardından söylenmek üzere on farklı kalıp söz ürettiği tespit edilmiştir.

Tablo 2.2. Türkçe öğretmeni adaylarının "ölüm" için kullandıkları kalıp sözler (ölenin yakını için söylenen kalıp sözler)

\begin{tabular}{lcc}
\hline Kalıp Sözler: Ölüm (Ölenin yakını için) & Toplam Sıklık (f) & Yüzde (\%) \\
\hline başın(ız) sağ olsun & 106 & 53 \\
\hline Allah (kalanlara) sabır versin & 68 & 34 \\
\hline ölenle ölünmez & 7 & 3,5 \\
\hline Allah sizlere ömür versin & 5 & 2,5 \\
\hline Allah dayanma gücü versin & 3 & 1,5 \\
\hline Allah yardımcın(ız) olsun & 3 & 1,5 \\
\hline emir Allah'ın & 2 & 1 \\
\hline hepimizin gideceği yer orası & 2 & 1 \\
\hline metanetli olun & 2 & 1 \\
\hline geride kalanlar sağ olsun & 1 & 0,5 \\
\hline ölümlü dünya & 1 & 0,5 \\
\hline
\end{tabular}




\begin{tabular}{lll}
\hline Toplam & 200 & 100 \\
\hline
\end{tabular}

Tablo 2.2'de görüldüğü gibi, öğretmen adayları, ölen kişinin yakınına baş sağlığı dilerken, en çok "başın(ız) sağ olsun (\%53)" ve "Allah kalanlara sabır versin (\%34)" kalıp sözlerini kullanmışlardır. Bunu sırasıyla "ölenle ölünmez (\%3,5)", "Allah sizlere ömür versin $(\% 2,5)$ ”, "Allah dayanma gücü versin $(\% 1,5)$ ", "Allah yardımcın(ız) olsun (\%1,5)", "emir Allah'ın (\%1)", "hepimizin gideceği yer orası (\%1)", "metanetli olun (\%1)", "geride kalanlar sağ olsun $(\% 0,5)$ ", "ölümlü dünya $(\% 0,5)$ " kalıp sözleri takip etmiştir. Öğretmen adayları ölen kişinin yakınına baş sağlığı dilemek için on bir farklı kalıp söz kullanmışlardır.

Tablo 2.3. Türkçe öğretmeni adaylarının "doğum" için kullandıkları kalıp sözler

\begin{tabular}{lll}
\hline Kalıp Sözler: Doğum & Toplam Sıklık (f) & Yüzde (\%) \\
\hline Allah analı babalı büyütsün + & 117 & 65,7 \\
\hline hayırlı olsun & 18 & 10,1 \\
\hline tebrikler/tebrik ederim & 16 & 9 \\
\hline Allah uzun ömür versin+ & 4 & 2,2 \\
\hline Allah bağışlasın & 3 & 1,7 \\
\hline gözünüz aydın & 3 & 1,7 \\
\hline maşallah+ & 3 & 1,7 \\
\hline ömrü uzun olsun+ & 3 & 1,7 \\
\hline sağlıkla büyüsün+ & 3 & 1,7 \\
\hline bahtı açık olsun+ & 2 & 1,1 \\
\hline Allah evliliğini de göstersin & 1 & 0,6 \\
\hline Allah hayırlı evlat kılsın & 1 & 0,6 \\
\hline Allah dört gözle büyütmeyi nasip etsin+ & 1 & 0,6 \\
\hline hayırlı ömürlü olsun+ & 1 & 0,6 \\
\hline vatana millete hayırlı evlat olsun & 1 & 0,6 \\
\hline yaşı uzun olsun+ & 1 & 0,6 \\
\hline Toplam & 178 & 100 \\
\hline
\end{tabular}

Türkçe öğretmeni adayları "doğum" için \%65,7 gibi çok büyük bir oranla "Allah analı babalı büyütsün" kalıp sözünü kullanmışlardır. Bunu sırasıyla "hayırlı olsun (\%10,1)”, "tebrikler/tebrik ederim (\%9)", "Allah uzun ömür versin (\%2,2)", "Allah bağışlasın (\%1,7)", "gözünüz aydın (\%1,7)", "maşallah $(\% 1,7)$ ”, “ömrü uzun olsun $(\% 1,7)$ ”, "sağlıkla büyüsün $(\% 1,7)$ ”, "bahtı açık olsun $(\% 1,1)$ ”, “Allah evliliğini de göstersin $(\% 0,6)$ ", "Allah hayırlı evlat kılsın $(\% 0,6)$ ", "Allah dört gözle büyümeyi nasip etsin $(\% 0,6)$ ", "hayırlı ömürlü olsun $(\% 0,6)$ ", "vatana millete hayırlı evlat olsun $(\% 0,6)$ ", "yaşı uzun olsun $(\% 0,6)$ " kalıp sözleri takip etmiştir.

"Doğum" durumunda kullanılan kalıp sözler incelendiğinde, sözlerin bir kısmının doğrudan dünyaya gelen bebek için dilenen iyi dilekler olduğu görülürken; bir kısmının da ebeveyn ve hatta toplum için dilenen iyi dilekler olduğu dikkati çekmektedir. Tabloda "artı (+) işareti" ile belirtilmiş olan “Allah analı babalı büyütsün, Allah uzun ömür versin, sağlıkla büyüsün, bahtı açık olsun vb.” kalıp sözler doğrudan bebek için istenen iyi dilekler iken; "Allah hayırlı evlat kılsın, tebrik ederim, gözünüz aydın vb." kalıp sözler ebeveyn için istenen iyi dileklerdir. 
Öğretmen adayları "doğum" bağlamında on altı farklı kalıp söz kullanmışlardır. Bu sözlerin dokuz tanesi doğrudan bebek için söylenen sözler, yedi tanesi ise ebeveyne hitaben söylenen sözlerdir. Toplam sıklık açısından ise kalıp sözlerin büyük çoğunluğu $(\% 75,9)$ dünyaya gelen bebek için söylenirken; daha az bir kısmı $(\% 24,1)$ ebeveyn ve toplum için söylenmiştir.

Tablo 2.4. Türkçe öğretmeni adaylarının "nişan/evlilik" için kullandıkları kalıp sözler

\begin{tabular}{lll}
\hline Kalıp Sözler: Nişan/Evlilik & Toplam Sıklık (f) & Yüzde (\%) \\
\hline Allah bir yastıkta kocatsın/bir yastıkta kocayın & 128 & 30,7 \\
\hline Allah tamamına erdirsin & 118 & 28,3 \\
\hline hayırlı olsun & 45 & 10,8 \\
\hline tebrikler/tebrik ederim & 42 & 10,1 \\
\hline mutluluklar & 37 & 8,9 \\
\hline Allah mesut etsin & 17 & 4,1 \\
\hline darısı başımıza & 10 & 2,4 \\
\hline Allah bozmasın & 6 & 1,4 \\
\hline Allah ayırmasın & 4 & 1 \\
\hline Allah daim etsin & 3 & 0,7 \\
\hline Allah utandırmasın & 3 & 0,7 \\
\hline mutluluğunuz daim olsun & 3 & 0,7 \\
\hline evinizin bereketi bol olsun & 1 & 0,2 \\
\hline Toplam & 417 & 100 \\
\hline
\end{tabular}

Tablo 2.4'te görüldüğü gibi Türkçe öğretmeni adayları "nişan/evlilik" bağlamında on üç farklı kalıp söz kullanmışlardır. Bunların içinde en çok, özellikle evlilik durumunda kullanılan, "Allah bir yastıkta kocatsın/bir yastıkta kocayın $(\% 30,7)$ " kalıp sözü ile yine özellikle nişan durumunda kullanılan "Allah tamamına erdirsin (\%28,3)" kalıp sözü kullanılmıştır. Geriye kalan kalıp sözler ise hem nişan hem de evlilik durumunda kullanılabilecek sözlerdir. Bunlar sırasıyla "hayırlı olsun $(\% 10,8)$ ", "tebrikler/tebrik ederim $(\% 10,1)$ ", "mutluluklar $(\% 8,9)$ ", "Allah mesut etsin $(\% 4,1)$ ", "darısı başımıza $(\% 2,4)$ ", "Allah bozmasın (\%1,4)", "Allah ayırmasın (\%1)", "Allah daim etsin $(\% 0,7)$ ", "Allah utandırmasın $(\% 0,7)$ ", "mutluluğunuz daim olsun $(\% 0,7)$ ", "evinizin bereketi bol olsun $(\% 0,2)$ ” kalıp sözleridir.

Tablo 2.5. Türkçe öğretmeni adaylarının "başarı" için kullandıkları kalıp sözler

\begin{tabular}{lll}
\hline Kalıp Sözler: Başarı & Toplam Sıklık (f) & Yüzde (\%) \\
\hline tebrikler/tebrik ederim & 89 & 42 \\
\hline başarılarının devamını dilerim & 80 & 37,7 \\
\hline aferin & 19 & 9 \\
\hline başarıların daim olsun & 6 & 2,8 \\
\hline bravo & 6 & 2,8 \\
\hline helal olsun & 4 & 1,9 \\
\hline maşallah & 4 & 1,9 \\
\hline helal sana & 3 & 1,4 \\
\hline kutlarım & 1 & 0,5 \\
\hline Toplam & 212 & 100 \\
\hline
\end{tabular}

Türkçe öğretmeni adayları başarı elde eden bir kişiye en çok \%42'lik bir oranla “tebrikler/tebrik ederim" ile \%37,7'lik bir oranla "başarılarının devamını dilerim" kalıp sözlerini söylemektedir. Bunu sırasıyla "aferin (\%9)", "başarıların daim olsun (\%2,8)", "bravo (\%2,8)", "helal olsun (\%1,9)", "maşallah 
$(\% 1,9) "$, "helal sana $(\% 1,4)$ ", "kutlarım $(\% 0,5)$ " sözleri takip etmiştir. Öğretmen adayları başarı bağlamında dokuz farklı kalıp söz kullanmışlardır.

Tablo 2.6. Türkçe öğretmeni adaylarının "mal/mülk edinme" için kullandıkları kalıp sözler

\begin{tabular}{lll}
\hline Kalıp Sözler: Mal/Mülk Edinme & Toplam Sıklık (f) & Yüzde (\%) \\
\hline hayırlı (uğurlu) olsun & 94 & 45,2 \\
\hline güle güle oturun/güle güle kullanın & 91 & 43,8 \\
\hline Allah kaza bela vermesin & 9 & 4,3 \\
\hline Allah huzurla oturmayı nasip etsin & 6 & 2,9 \\
\hline Allah güle güle oturmayı nasip etsin & 5 & 2,4 \\
\hline güzel günlerde oturun & 2 & 1 \\
\hline sağlıkla ve sıhhatle oturun & 1 & 0,5 \\
\hline Toplam & 208 & 100 \\
\hline
\end{tabular}

"Mal/mülk edinme" bağlamında öğretmen adayları yedi farklı kalıp söz kullanırken, sıklık açısından değerlendirildiğinde öğretmen adaylarının tamamına yakını (\%89) "hayırlı (uğurlu) olsun $(\% 45,2)$ " ve "güle güle oturun/güle güle kullanın $(\% 43,8)$ " kalıp sözlerini kullanmışlardır. Sonrasında sırasıyla "Allah kaza bela vermesin (\%4,3)", "Allah huzurla oturmayı nasip etsin (\%2,9)”, "Allah güle güle oturmayı nasip etsin $(\% 2,4)$ ", "güzel günlerde oturun $(\% 1)$ ", sağlıkla ve sıhhatle oturun $(\% 0,5)$ " kalıp sözleri kullanılmıştır.

Tablo 2.7. Türkçe öğretmeni adaylarının "bayramlarda" kullandıkları kalıp sözler

\begin{tabular}{lll}
\hline Kalıp Sözler: Bayram & Toplam Sıklık (f) & Yüzde (\%) \\
\hline bayramınız mübarek olsun & 36 & 39,1 \\
\hline iyi bayramlar & 24 & 26,1 \\
\hline bayramınız kutlu olsun & 18 & 19,6 \\
\hline hayırlı bayramlar & 11 & 12 \\
\hline nice bayramlara & 3 & 3,3 \\
\hline Toplam & 92 & 100 \\
\hline
\end{tabular}

Türkçe öğretmeni adayları "bayramlarda" en çok "bayramınız mübarek olsun $(\% 39,1)$ ", "iyi bayramlar (\%26,1)" ve "bayramınız kutlu olsun $(\% 19,6)$ " kalıp sözlerini kullanmaktadırlar. Bunların yanı sıra "hayırlı bayramlar (\%12)" ve "nice bayramlara $(\% 3,3)$ " ifadeleri kullandıkları diğer kalıp sözlerdir. Öğretmen adayları bayram kutlamak için madde başı olarak beş farklı kalıp söz kullanmışlardır.

Tablo 2.8. Türkçe öğretmeni adaylarının "hasta ziyaretinde" kullandıkları kalıp sözler

\begin{tabular}{lll}
\hline Kalıp Sözler: Hasta Ziyareti & Toplam Sıklık (f) & Yüzde (\%) \\
\hline geçmiş olsun & 128 & 57,9 \\
\hline Allah (acil) şifa(lar) versin & 86 & 38,9 \\
\hline kısa zamanda iyileşirsin inşallah & 5 & 2,3 \\
\hline dikkat et kendine & 1 & 0,5 \\
\hline gelmiş geçmiş olsun & 1 & 0,5 \\
\hline Toplam & 221 & 100 \\
\hline
\end{tabular}

Hasta ziyareti için öğretmen adaylarının neredeyse tamamı $(\% 96,8)$, "geçmiş olsun $(\% 57,9)$ " ve “Allah (acil) şifa(lar) versin (\%38,9)” kalıp sözlerini kullanmayı tercih etmişlerdir. Bu sözleri sırasıyla "kısa zamanda iyileşirsin inşallah $(\% 2,3)$ ", "dikkat et kendine $(\% 0,5)$ " ve "gelmiş geçmiş olsun $(0,5)$ " 
kalıp sözleri takip etmiştir. Öğretmen adayları hasta ziyareti bağlamında beş farklı kalıp söz söylemişlerdir.

\section{Tartışma, Sonuç ve Öneriler}

Kalıp sözler, söylenmek istenen duygu ve düşüncelerin anlamını güçlendiren, içinde toplumun hayata bakışını, yaşam biçimini, inançlarını barındıran; kısacası kültürünü yansıtan kalıplaşmış söz varlığı unsurlarıdır.

Türkçe öğretmeni adaylarının özel durumlarda kullandıkları kalıp sözleri tespit etmek amacıyla yapılan bu çalışmada "ölüm, doğum, nişan/evlilik, başarı, mal/mülk edinme, bayram ziyareti ve hasta ziyareti" olmak üzere yedi farklı bağlama ilişkin veri elde edilmiştir. Araştırma sonucunda elde edilen bulgular, "Türkçe öğretmeni adaylarının özel durumlarda kullandıkları kalıp sözlere ilişkin sayısal bulgular" ve "Türkçe öğretmeni adaylarının özel durumlarda kullandıkları kalıp sözler" olmak üzere iki alt başlıkta ele alınmıştır.

Birinci alt başlık olan “Türkçe öğretmeni adaylarının özel durumlarda kullandıkları kalıp sözlere ilişkin sayısal bulgulara" göre çalışmaya katılan 173 öğretmen adayı toplamda 72 madde başı kalıp söz söylerken bu sözlerin toplam sıklığı 1896 olmuştur. Cinsiyete göre madde başı kalıp söz kullanımında belirgin bir fark çıkmazken (kız: 0,6; erkek: 0,7); toplam sıklık açısından kızların (11,3), erkeklerden $(10,5)$ daha fazla kalıp söz kullandıkları görülmüştür. Bu durum kalıp sözlerin kızlar arasındaki kullanım sıklığının daha fazla olduğunu göstermektedir. Söz varlığı üzerine yapılan birçok çalışmada, kelimelerin toplam sıklığı açısından, kızların erkeklerden daha fazla puan aldıkları görülmektedir (Temur, 2006; Hancı, 2007; Türkyılmaz, 2013; İpek Eğilmez, 2017). Kelime hazinesi ile cinsiyet değişkeni arasındaki ilişkiye dayanan bazı araştırmalarda, özellikle erken çocukluk dönemlerinde, kızların dil gelişimlerinin ve kelime dağarcıklarının daha iyi olduğu gözlenirken (Aydoğan ve Koçak, 2003); daha büyük yaşlarda cinsiyet açısından büyük farklar çıkmadığı görülmektedir (Öztürk, 1995; İpek ve Bilgin, 2007). Bu durum dil gelişimi üzerinde cinsiyet faktörünün ilerleyen yıllarda etkisinin azalarak; eğitim, sosyoekonomik düzey, aile eğitim düzeyi gibi çevresel faktörlerin etkisinin artmasıyla açıklanabilir.

Öğretmen adaylarının bağlamlara göre kullandıkları kalıp sözler madde başı kullanım açısından incelendiğinde, adayların, en çok "ölüm $(\% 30,6)$ " ve "doğum $(\% 22,2)$ " bağlamına ilişkin kalıp söz ürettikleri görülmüştür. Bir başka deyişle öğretmen adaylarının, çalışmaya dâhil edilen bağlamlar içerisinde, en çok ölüm ve doğuma ilişkin kalıp söz çeşitliliğine ve zenginliğine sahip olduğu belirlenmiştir. Araştırma sonucunda öğretmen adaylarının madde başı olarak en çok kalıp söz ürettikleri bağlam olan "doğum ve ölüm”, yaşamın iki ana dönüm noktasıdır. İnsanı duygusal anlamda kalıcı olarak en fazla etkileyen böylesi yaşamsal iki kavrama ilişkin Türkçenin zenginliği ve Türk kültürün içindeki önemi de ortaya çıkmaktadır. Türk kültüründe doğum, anne, aile, yuva, vatan kutsaldır. Ölüm, 
kalpte yumuşama sağlayarak affetme duygusunu beraberinde getirir. Ölen kişi hayattayken sevilmiyor bile olsa arkasından konuşulması doğru bulunmaz, ona hak helal edilir. Aksan'a göre (2008, s. 21) "dünyaya gelen insanoğlu maddi ve manevi kavramları, kendi anadilinin kalıp ve değerleriyle algılamakta, içinde yer aldığı toplumun kültür ögelerini, dünya görüşünü, yaşam biçimini, inanç ve geleneklerini içeren kavramları diliyle edinmektedir."

Madde başı olarak kullanılan kalıp söz sıralamasını, ölüm ve doğumdan sonra, sırasıyla, "nişan/evlilik, başarı, mal/mülk edinme, bayram ziyareti ve hasta ziyareti" bağlamları almıştır. Özel durumlarda kullanılan kalıp sözlerin toplam sıklığı açısından ise öğretmen adaylarının en çok "ölüm, nişan/evlilik, hasta ziyareti" bağlamlarında kalıp sözleri tekrar ettikleri görülmüştür.

Araştırma bulgularının ikinci alt başlığı olan "Türkçe öğretmeni adaylarının özel durumlarda kullandıkları kalıp sözler" bölümünde, öğretmen adaylarının her bir bağlama ilişkin kullandıkları kalıp sözler kullanım sıklıkları ile birlikte verilmiştir.

Öğretmen adaylarının madde başı olarak en çok "farklı kalıp söz" ürettikleri bağlam olan "ölüm” durumunda söylenen sözler, "ölen kişi için" ve "ölen kişinin yakını için" olmak üzere iki ayrı tabloda ele alınmıştır. Ölen kişi için daha çok Allah'tan rahmet, af, cennet dileğinde bulunulurken; ölen kişinin yakını için sağlık, sabır, uzun ömür dileğinde bulunulmuştur. Ölenin ardından söylenen sözler daha çok sabretmeye ve metîn olmaya yönlendiren teselli edici sözlerdir. Ölüm olgusuyla ilgili olarak dikkati çeken bir diğer nokta, bu bağlamda söylenen sözlerin ahiret inancıyla doğrudan ilişkili oluşudur. Konu ile ilgili olarak Aksan (2008, s. 22), "bir toplumun geçirdiği bütün kültürel değişimlerin dilde yankısını bulduğunu" ifade etmektedir. Ona göre (2008, s. 22), Türklerin Uygurlar döneminde Budizm ve Maniheizm dinlerini benimsemeleri; inançlarıyla birlikte bu dillerin kavramlarının, terimlerinin, birçok anlatım biçimlerinin Türkçeye girmesine; X. Yüzyılda İslamiyet'in benimsenmesiyle bu yeni dinin kavramlarının dile alınmasına; söz varlığımızda terim, deyim, atasözü, ilişki sözleri, hayır dua ve beddualarda İslamiyet'in getirdiği unsurların yoğunlaşmasına yol açmıştır. Ölüm bağlamı ile ilgili olarak ortaya çıkan bir başka sonuca göre, öğretmen adayları, ölen kişinin yakının teselli etmek için "emir Allah'ın" kalıp sözünü kullanırlarken benzer bir anlam içeren "takdiri ilahi" sözünü kullanmamışlardır. Diğer söz varlığı unsurlarında da olduğu gibi, kullanılan kalıp sözlerin tercihinin, kişinin yaşıyla, eğitimiyle, mesleğiyle, cinsiyetiyle, sosyoekonomik durumuyla doğrudan ilişkili olduğu söylenebilir.

"Doğum" durumunda öğretmen adayları en çok "Allah analı babalı büyütsün $(\% 65,7)$ " demişlerdir. Duygusal, ruhsal, fiziksel vb. ihtiyaçların karşılanabilmesi için dünyaya gelen bir bebeğe dilenebilecek en güzel dileklerin başında "Analı babalı büyümesi" gelmektedir. Bir çocuk doğduğunda onun için iyi dilekler dilemek her toplumdan beklenecek bir durumdur. Fakat kişilerin ne dileyeceği doğrudan o toplumun öncelikleri, önemsedikleri, inandıkları, yaşamdan beklentileri ile ilgilidir. Bir 
çocuğun analı babalı büyümesini, o anne baba için hayırlı evlat olmasını, uzun ömürlü olmasını, sağlıkla büyümesini ve hatta vatanına milletine hayırlı evlat olmasını dilemek, çocuğun, "hem birey olarak iyi, sağlıklı ve uzun bir yaşam sürmesini hem de vatan ve millet adına hayırlı, faydalı bir insan olmasını" isteme anlamlarını taşımaktadır. Doğan bebek için "vatana millete hayırlı evlat olsun" kalıp sözünü kullanan kişilerin vatan ve millet kavramlarını öncelikli buldukları söylenebilir. Bu kalıp söz ile nasıl anne baba çocuğun ebeveyniyse toplum da çocuğun bir ebeveyni olarak düşünülmekte ve böylece çocuğun anne babaya karşı olduğu kadar topluma karşı görev ve sorumlulukları olduğu ifade edilmektedir.

Nişan/evlilik durumunda, nişan için en çok "Allah tamamına erdirsin"; evlilik için en çok "Allah bir yastıkta kocatsın/bir yastıkta kocayın" kalıp sözleri kullanıımıştır. Bu bağlamda söylenen kalıp sözlerden "darısı başımıza” sözü aslında, nişan veya evlilik aracılı̆ııyla mutluluğa eren kişi tarafından kendisine iyi dilekte bulunan kişiye "sen de bu mutluluğa er" demek maksadıyla söylenen bir iyi dilek sözü olmasına rağmen genç öğretmen adayları bu kalıp sözü kendilerine hitaben söylemişlerdir. Yine "nişan/evlilik" bağlamında söylenen kalıp sözler incelendiğinde bu sözlerin çoğunlukla yuva kurmak için bir araya gelen kişilerin ömür boyu birlikte olmaları, mutluluklarının daim olmaları üzerine olduğu görülmektedir.

Bir başarı elde eden kişi için çoğunlukla "tebrikler/tebrik ederim, başarılarının devamını dilerim" sözleri kullanılmıştır. Buna ek olarak öğretmen adayları "aferin, bravo” vb. kalıp sözlerin yanında biraz da tezahürat ifadesi içeren "helal sana, helal olsun" vb. ifadeler kullanmışlardır. Kişilerin kullandığı söz varlığı unsurları onların yaşları, cinsiyetleri, eğitimleri, meslekleri, sosyoekonomik ve kültürel düzeyleri ile de ilişkilidir. Keklik'e göre (2010, s. 4) “Çocuğun başlangıçta annesinden öğrendiği dil, ailesinin, yakın çevresinin sosyal ve kültürel seviyesine göre değişmektedir. Çocuğun yaşı ilerleyip ihtiyaçları çeşitlendikçe, kelime hazinesi de genişlemektedir."

$\mathrm{Mal} /$ mülk edinme durumunda öğretmen adaylarının çoğunluğu "hayırlı (uğurlu) olsun ve güle güle oturun/güle güle kullanın" kalıp sözlerini kullanmışlardır. Edinilen mal bir araçsa "hayırla, sağlıkla, kazasız bir şekilde kullanma"; edinilen mal bir evse "hayırla, sağlıkla, mutlulukla oturma" dileklerinde bulunulmuştur.

Öğretmen adayları bayram günlerinde birbirlerinin/büyüklerinin bayramlarını kutlamak için çoğunlukla "bayramınız mübarek olsun, iyi bayramlar, bayramınız kutlu olsun vb." kalıp sözleri kullanırlarken; bayramı kutlanan kişinin söyleyeceği “berhudar ol, çok bayramlara er, el öpenlerin çok olsun vb." kalıp sözleri kullanmamışlardır. Bu kalıp sözler, bayramlarda, genellikle yaşları büyük olan kişilerin kullandıkları sözlerdir.

Hasta ziyareti sırasında öğretmen adayları çoğunlukla "geçmiş olsun ve Allah (acil) şifa(lar) versin” kalıp sözlerini kullanmışlardır. Yine burada özellikle son yıllarda kullanımı moda bir söz olan 
"dikkat et kendine" ifadesi hasta ziyareti sırasında öğretmen adaylarının söyledikleri bir söz olarak ortaya çıkmıştır.

Tebrikler/tebrik ederim kalıp sözü birçok bağlamda kullanılabilen bir sözdür. Türkçe öğretmeni adayları bu kalıp sözü, "doğum, "nişan/evlilik, başarı” durumlarında kullanmışlardır. Bir kalıp söz yeri geldiğinde birden fazla durumda kullanılabilmektedir. Örneğin "teşekkür ederim" kalıp sözü teşekkür ederken kullanılabileceği gibi bir isteği kabul ederken veya reddederken de kullanılmaktadır (İpek Eğilmez, 2017, s. 790).

Genel olarak değerlendirildiğinde hemen her bağlamda söylenen kalıp sözlerde sağlık, mutluluk, uzun ömür dilendiği ve bunların sürekliliğinin istendiği görülmektedir. Bazı durumlarda iyi dileklerin olumsuzu olumsuzlayarak dile getirildiği görülürken; bazı durumlarda doğrudan olumlu kalıplarla dile getirildiği görülmüştür. "Sağlıkla kullanın" yerine "Allah kaza bela vermesin"; "mutluluğunuz daim olsun" yerine "Allah ayırmasın" veya "Allah bozmasın” örneklerinde olduğu gibi. Kişilerin bu tercihi, onların, duygu dünyaları ve/veya duygu dünyalarında kelimelerin karşılık geldiği "duygu değeri" ile açıklanabilir. Bir sözcüğün duygu değeri, o sözcüğün bağlam içinde çağrıştırdığı ruhsal anlam ile ilgili olduğu gibi sözcüklerin insanların ruhundaki etkisiyle de ilgilidir ve bu etki kişiden kişiye değişiklik göstermektedir (Uçan, 2010, s. 36).

İnsanlar arasındaki ilişkiyi güçlendiren kalıp sözler doğru yerde ve doğru zamanda kullanıldığında oldukça etkili olmaktadır. Okullarda Türkçe eğitimi sırasında nasıl sözcük öğretimi, atasözü ve deyim öğretimi yapılıyorsa kalıp sözlerin öğretimine de zaman ayrılmalıdır. Bu amaç doğrultusunda Türkçe öğretmenleri ve öğretmen adaylarına tavsiyelerde bulunulmalıdır. Bir bağlamda en çok kullanılan kalıp sözler tespit edilerek hem anadili eğitiminde hem de yabancılara Türkçe öğretiminde öncelikli olarak öğretilecek kalıp sözler belirlenmelidir.

Kalıp söz öğretimi belirli bağlam gerçekleştiğinde kullanılmaktadır. Bu nedenle özellikle okullarda kalıp söz öğretimi yapıırken canlandırma ve drama tekniğinden faydalanılmalıdır. Böylece çocuklar olayın içine girerek hangi durumda hangi sözü kullanmaları gerektiğini daha doğru ve açık bir şekilde fark edebileceklerdir.

En kolay ulaşılabilir ders materyali olan ders kitaplarında ve çocuk kitaplarında kalıp sözlerin kullanıldığı bölümler aracılığı ile bu sözlerin öğretimi desteklenebilir. Çalışma farklı bölümlerde öğrenim gören öğrencilerle, yaşça daha büyük bir örneklem grubu ile veya farklı sosyoekonomik ve kültürel düzeylerde yapıldığında çok daha farklı kalıp sözlerin ortaya çıkacağı düşünülmektedir.

\section{Kaynaklar}

Aksan, D. (2003). Her yönüyle dil. Ana çizgileriyle dilbilim. Ankara: Türk Hava Kurumu.

Aksan, (D. (2008). Türkçeye yansıyan Türk kültürü. Ankara: Bilgi. 
Aksan, D. (2014). Anadilimizin söz denizinde. Ankara: Bilgi.

Aksan, D. (2015). Türkçenin sözvarlığı. Ankara: Bilgi.

Aydoğan, Y., Koçak, N. (2003). Okulöncesi çocukların dil gelişimlerine etki eden faktörlerin incelenmesi. Milli Eğitim Dergisi, 159.

Bulut, S. (2012). Anadolu ağızlarında kalıp sözler ve kullanım özellikleri. Yayımlanmamış yüksek lisans tezi. Ordu Üniversitesi Sosyal Bilimler Enstitüsü, Ordu.

Büyüköztürk, Ş., Kılıç Çakmak, E., Akgün Ö., E., Karadeniz, Ş. ve Demirel, F. (2013). Bilimsel araştırma yöntemleri. Ankara: Pegem Akademi.

Canbulat, M. ve Dilekçi, A. (2013). Türkçe ders kitaplarındaki kalıp sözler ve öğrencilerin kalıp sözleri kullanma düzeyleri. TurkishStudies-International PeriodicalForTheLanguages, LiteratureandHistory of TurkishorTurkic, 8 (7), 217-232. doi:10.7827/TurkishStudies.5474

Çaydaş, A. (2016). Gazi üniversitesi TÖMER ve İzmir yabancılar için Türkçe öğretim setlerinde kullanılan kalıp sözlerin incelenmesi. Yayımlanmamış yüksek lisans tezi. Nevşehir Hacı Bektaş Veli Üniversitesi Sosyal Bilimler Enstitüsü, Nevşehir.

Erol, Ç. (2007). Türkiye Türkçesinde kalıp sözler üzerine bir inceleme. Yayımlanmamış yüksek lisans tezi. İstanbul Üniversitesi Sosyal Bilimler Enstitüsü, İstanbul.

Ertürk Şenden, Y. (2017). Türkçenin yabancı dil olarak öğretiminde kalıp sözlerin kullanımına yönelik etkinlik örneklerinin başarı üzerindeki etkileri. Yayımlanmamış yüksek lisans tezi. Gaziosmanpaşa Üniversitesi Eğitim Bilimleri Enstitüsü, Tokat.

Gökdayı, H. (2008). Türkçede kalıp sözler. Bilig, 44, 89-110.

Gökdayı, H. (2015). Türkçede kalıp sözler. İstanbul: Kriter.

Gökdayı, H. (2016). Yabancılara Türkçe öğretiminde sözcük öğretimi ve kalıp sözler. TurkishStudies-International PeriodicalForTheLanguages, LiteratureandHistory of TurkishorTurkic, 11 (19), 379-394. doi: http://dx.doi.org/10.7827/TurkishStudies.11131

Güvenç, B. (1996). Kültür ve demokrasi. Ankara: Gündoğan.

Hancı, G. (2007). İlköğretim 5. sınıf öğrencilerinin yazılı anlatımlarındaki aktif kelime servetinin belirlenmesi (Uşak/Banaz örneği). Yayımlanmamış yüksek lisans tezi. Afyon Kocatepe Üniversitesi Sosyal Bilimler Enstitüsü. Afyonkarahisar.

İlhan, N. (2017). Dil öğretiminde kalıp sözlerin, şiirin önemi/etkisi. TurkishStudies-International PeriodicalForTheLanguages, LiteratureandHistory of TurkishorTurkic, 12(22), 401-412. doi: http://dx.doi.org/10.7827/TurkishStudies.12348

İpek, N. ve Bilgin, A. (2007). İlköğretim çağı çocuklarında kelime dağarcığı gelişimi. ilköğretim Online, 6(3), 344365.

Ipek Eğilmez, N. (2017). Türkçe öğretmeni adaylarının günlük yaşamlarında kullandıkları "kalıp sözler". International Online Journal of EducationalSciences, 9(3), 784-805.

Kara, M.,Memiş, M., R. (2015). Yabancı dil olarak Türkçe öğrenenlerin kalıp ifadeleri kullanmadaki yeterlilik düzeyleri. International Journal of Languages' EducationandTeaching, UDES 2015, 1670-1681. doi: 10.18298/ijlet.297

Kara, M., Yıldırım. (2017). Nasreddin hoca fıkralarında kalıp sözler. International Journal of Languages' EducationandTeaching, 5(1), 487-489. doi: 10.18298/ijlet.1737

Karasar, N. (1999). Bilimsel araştırma yöntemi. Ankara: Nobel.

Keklik, S. (2010). Türkçede 0-6 yaş çocuklarına öğretilmesi gereken en sık kullanılan 1200 kelime. Türkiye Sosyal Araştırmalar Dergisi. 3, 1-28. 
Koç, B. (2015). Türkçe öğrenen yabancıların kalıp sözleri kullanabilme yeterlikleri (Bosna Hersek örneği). Yayımlanmamış yüksek lisans tezi. Gazi Üniversitesi Eğitim Bilimleri Enstitüsü, Ankara.

Kula, O. B. (1996). Dilin kültürelliği ya da kültürün dilselliği. Bilim ve Ütopya, 23, 46-47.

Öztürk, H. (1995). Okulöncesi eğitim kurumlarına giden ve gitmeyen ilkokul birinci sınıf öğrencilerinin alıcı ve ifade edici dil düzeyleri. Yayınlanmamış yüksek lisans tezi. Gazi Üniversitesi Sosyal Bilimler Enstitüsü. Ankara.

Sis N. ve Gökçe, B. (2009). Gülten Dayıoğlu'nun çocuk öykülerinde yansımalar ve kalıp sözler. TurkishStudiesInternational PeriodicalForTheLanguages, LiteratureandHistory of TurkishorTurkic, 4(3), 1975-1989.

Temur, T. (2006). Illköğretim 4. ve 5. sınıf öğrencilerinin yazı dilindeki kelime hazinelerinin bazı değişkenler açısından incelenmesi. Yayımlanmamış doktora tezi. Gazi Üniversitesi Eğitim Bilimleri Enstitüsü. Ankara.

Topçuoğlu Ünal, F. ve Bursalı, H. (2015). Çizgi dizilerle kalıp (ilişki) söz öğretimi: Cille örneği. Akademik Sosyal Araştırmalar Dergisi, 3(12), 69-83.

Türkyılmaz, M. (2013). Ortaokul 5. sınıf öğrencilerinin yazılı anlatımdaki aktif kelime hazinesinin belirlenmesi (Kırşehir/Akçakent örneği). Yayımlanmamış yüksek lisans tezi. Gazi Üniversitesi Eğitim Bilimleri Enstitüsü. Ankara.

Uçan, Hilmi, (2010), Söylem gösterge bilimi ve duygu değeri: Tevfik Fikret'in "Sitayiş-i Hazret-i Padişâhî" ve "Sis" şiirlerinde sevgi ve nefret, Sosyal Bilimler Dergisi, 12(2), 31-50.

Uzcu Yıldız, F. (2017). Yabancı Dil Olarak Türkçede Kalıp Söz Edinci. International Journal of Language Academy, 5(2), Türkçenin Eğitimi-Öğretimi Özel Sayısı, 129-140. doi: http://dx.doi.org/10.18033/ijla.3554

Ünsal, G. (2013). Dil öğretiminde kalıp sözler ve çevirisi. TurkishStudies-International PeriodicalForTheLanguages, LiteratureandHistory of TurkishorTurkic, 8(8), 1383-1394. doi:10.7827/TurkishStudies.5370

Yazıcı Okuyan, H. (2012). Illköğretim Türkçe ders kitaplarında bir kültür aktarımı aracı olarak kalıp sözlerin kullanımı üzerine bir inceleme. Türkiye Sosyal Araştırmalar Dergisi, 16(2), 31-46.

Yılmaz, F., Ertürk Şenden, Y. (2014). Türkçenin yabancı dil olarak öğretiminde kalıp sözlerin etkinliklerle öğretimi. Asya Öğretim Dergisi, 2(1(Özel)), 53-63.

Yılmaz, F., Ertürk Şenden, Y. (2015). Yabancılara Türkçe öğretiminde kalıp sözler: "Babam ve Oğlum” film örneği. International Journal of SocialScience, 32, 187-202. doi: http://dx.doi.org/10.9761/JASSS2683

Zülfikar, H. (2007). Dünden bugüne Türkçe (kalıp cümleler). Türk Dili Dergisi, 668, 344-351.

\section{Extended Abstract \\ Introduction}

Vocabulary is not the sum of individual words; rather it is a large unity of meanings constituted by idioms, proverbs, reduplications, formulaic expressions, terms and translated words. Among the elements of vocabulary, the most important elements assuming the duty of culture transfer are the "formulaic linguistic units" made up of proverbs, idioms, reduplications, compounds and formulaic expressions (Gökdayı, 2015, p. 33).

Formulaic expressions are the products of the society's long-time experiences; that is, they emerge from the sufferings, joys and experiences of the society. In a "fixed linguistic unit", what was felt by the society in a similar situation years ago may be found. This expressed emotion has infiltrated into the formulaic expression. For example, it is not possible to express, by using other words or word combinations, the feelings conveyed by the formulaic expressions used for the birth of a baby such as "Allah analı babalı büyütsün", "Uzun ömürlü olsun", or "Allah dört gözden ayırmasın" or those that are used to express condolences when someone loses a kin such as "Mekânı cennet olsun" or "Nur içinde yatsın".

As formulaic expressions are fixed lexical items that regulate societal and cultural relations, they may be analyzed as "fixed phrases" used "in everyday life" and as those that are used "on special occasions" depending on the context in which they are used. Formulaic expressions used in daily life are used in most common situations that people can encounter in their daily lives such as greetings, inquiring about someone's health, meeting someone, and apologizing. Formulaic expressions that are used on special occasions such as death, birth, marriage are also parts of our lives, but they mark rarer special occasions; therefore, they may be analyzed as a different kind of formulaic expressions used to regulate special occasions in life. 
Formulaic expressions that are parts of the language must also be a part of language teaching. In effective language teaching, besides the Turkish course curriculum and textbooks, the importance of Turkish teachers who are practitioners is enormous. In Turkish courses, which are based on direct interaction, students discover the richness of their mother tongue by listening, speaking, reading, and writing, and they gain the ability to use these skills masterfully. Therefore, it is of great importance for students to be introduced to high quality linguistically texts and also to interact with teachers, using the language effectively. Thus stated, the purpose of this study is to determine the extent to which prospective Turkish teachers use formulaic expressions.

\section{Method}

The current study employed the survey model aiming to reveal an existing situation as it is (Karasar, 1999: 77). The study group of the current research comprised 173 prospective Turkish teachers attending the Turkish Teaching department in the Education Faculty of Muğla Sıtkı Koçman University in the 2015-2016 academic year. In the formation of the study group, purposive sampling method was used.

The data were collected by using the "Formulaic Expression Use Test" developed by the researcher. In this regard, first the related literature was reviewed to determine the formulaic expressions that were used on "special occasions", and the example phrases used in such contexts were listed. The draft version of the test was reviewed by six field experts, and, in the light of their suggestions, the final form of the test was given. The prospective teachers were asked to write which formulaic expressions they used on those given special occasions. Based on the responses given by the participants, a total of 9 different contexts emerged. In this study, seven most common special occasions were focused on; those are "birth", "death", "engagement/marriage", "success", "acquisition of property", "eid visit" and "patient visit". The collected data were analyzed, using "SPSS 22", "Simple Concordance Program 4.07" and "Microsoft Excel".

\section{Result and Discussion}

The results of the study revealed that the participants produced a total of 72 different formulaic expressions and the total frequency of the expressions was 1896. While no significant difference was found in the use of the formulaic expressions in terms of gender (female: 0.6; male: 0.7); in terms of total frequency, females used more formulaic expressions (11.3) than males (10.5). This finding is compatible with other studies in which females had higher scores than males in terms of the total frequency of use (Temur, 2006; Hancl, 2007; Türkyılmaz, 2013; İpek Eğilmez, 2017).

When the use of formulaic expressions used in context was examined in terms of each formulaic phrase, it was found that the participants produced formulaic expressions the most in the contexts of "death" (30.6\%) and "birth" (22.2\%). "Birth" and "death" are two main turning points in life. This shows that these concepts have a huge impact on people's emotions in the Turkish culture, and they show the richness of the Turkish language. In the Turkish culture, birth, mother, family, home, and homeland are sacred. Death brings about softness in the heart, leading to a desire to forgive. Even if the deceased was not a loved person when he/she was alive, speaking ill of the deceased is not considered morally appropriate.

In terms of the frequency of individual use of formulaic expressions, "death" and "birth" are followed by the contexts "engagement/marriage", "success", "acquisition of property", "eid visit", and "patient visit". In terms of the total frequency of use, the prospective teachers were found to have repeated the formulaic expressions mostly in the contexts of "death", "engagement/marriage", and "patient visit".

The analysis of the formulaic expressions produced by the prospective Turkish teachers in the context of "death" which the highest number of items showed that two types of utterances were produced in this context: those produced for "the deceased" and those for "the relatives of the deceased". For the deceased, while the formulaic expressions are mostly related to blessing from God, forgiveness, and paradise; the formulaic expressions used for the relatives of the deceased are mostly related to wishes for health, patience, and long life. The formulaic expressions uttered after the deceased are mostly words of consolation. Another significant point concerning the phenomenon of death is that the formulaic expressions produced in this context are directly related to faith and the hereafter. In this connection, Aksan (2008, p. 22) states that "all the cultural transformations experienced by a society have some reflections on the language." According to him (2008, p. 22), with the adoption of the religions of Buddhism and Manichaeism by the Turks during the Uighur era, many concepts, terms and phrases entered Turkish; with the adoption of Islam in the 10th century, many concepts of this new religion entered Turkish, resulting in an increasing effect of Islam on the contents of terms, idioms, proverbs, formulaic expressions, blessings, and curses used.

In the context of "birth", the prospective teachers used the formulaic expression "Allah analı babalı büyütsün" the most (65.7\%)". One of the best wishes for a newly born child is for that child to grow up under the care of his/her parents so that his/her emotional, spiritual, and physical needs can be met. When a child is born, good wishes for him/her are made in every society. But, what people say depends on their priorities, considerations, beliefs, and expectations in life. To wish for a child to grow up under the care of his parents, to 
be a good child for the parents, to live long, to grow up healthily and to be a good citizen for his/her country/nation/to the motherland/to the nation means that the child should be able to live a good life both as an individual and to be a good and beneficial member of the country and nation. With the formulaic expression "Vatana millete hayırlı evlat olsun", it is meant that the mother and the father and the society are seen as the family of the child, and, thus, the child is responsible for not only for his parents but also for the society.

Regarding the context of "engagement/marriage", the formulaic expressions used the most frequently in engagement is "Allah tamamına erdirsin", and in marriage, it is "Allah bir yastıkta kocatsın/Bir yastıkta kocayın". Though one of the formulaic expressions used in this context, "Darısı başımıza" is used by individuals who are newly engaged or married in response to good wishes made for him/her, the prospective teachers used this expression for themselves.

The prospective teachers used the formulaic expressions "Tebrikler/Tebrik ederim, Başarılarının devamını dilerim" to congratulate someone on his/her success; "Hayırlı (uğurlu) olsun" and "Güle güle oturun/Güle güle kullanın" in the context of gaining the possession of a new property; in the context of "eid visits", "Bayramınız mübarek olsun, İyi bayramlar, Bayramınız kutlu olsun"; and in the context of "patient visit", "Geçmiş olsun" and "Allah (acil) şifa(lar) versin".

When evaluated in general, the formulaic expressions used in almost any context in the current study are related to the wishes for good health, happiness, and long life. In some situations, good wishes are expressed by using expressions positive in meaning, yet negative in structure; for example, "Allah kaza bela vermesin" instead of "Sağlıkla kullanın"; "Allah ayırmasın" instead of "Mutluluğunuz daim olsun" or "Allah bozmasın". 